\title{
The Effect of Using Role Play Strategy on Tenth Grade Students' Performance in Reading Skill at Public Schools in Amman
}

\author{
Dr. Mona Smadi \\ Assistant Professor \\ Princess Alia University College \\ Al Balqa Applied University, Amman \\ Jordan
}

\begin{abstract}
The purpose of this study is to investigate the effect of using Role play strategy on tenth grade students'performance inEnglish Language reading skill in public schools in Jordan.To achieve the purpose of the study, a pre/post-test was constructed to measure students' performance in English language reading skill. The sample of the study comprised (256) tenth grade students in public schools in Amman and was distributed into four sections, which were selected purposefully. The sample of the study was distributed into four groups (two experimental and two control groups). The experimental group's students were taught the reading skill using the Role-play strategy while the control groups' students were taught using the traditional way. The sample of the study was (128) students in the experimental group and (128) students in the control group. Those groups were distributed into four purposefully selected sections in public schools in Amman. Theresults of the study showed a variance in the means of the achievement test according togroup, it also showed that there were statistically significant differences on theachievement test due to the Strategy variable. There were statistically significantdifferences between the Role play Strategy and the Current Strategy in favor of the Role play Strategy, and there was no statistically significant difference in thestudents' achievement due to gender. There was no statistically significant difference due tothe interaction between gender and group.The researchers recommend that EFL researchers focus on new teaching strategies and conductmore studies related this topic. They also recommend that other researchers conductstudies and focus on the Role play Strategy.
\end{abstract}

Keywords: Strategies for teaching English, Role play Strategy, Traditional way

\section{Introduction}

The knowledge of the age at which we are living is rapidly changing. The most important manifestation of this phenomenon is the knowledge explosion. Knowledge is no longer fixed, but it has become variable and infinite. This has led to an increase in knowledge. The knowledge provided to our generations in educational institutions is no longer usable and applied. This raises several questions, including: What are the most appropriate methods to interact with knowledge? What is the criterion for judging how learners benefit from that knowledge? (Sa'ada and Ibrahim, 2001). The diversity of teaching methods in accordance with modern educational trends can contribute to this challenge by developing the student's ability to think. "Students gain a much better way of thinking than they do, as accumulated information is forgotten after a short period of time. Self-learning that enables them to learn how to learn, and help them to use the learning resources and knowledge available in the surrounding environment"(Khadr, 2006). The teaching process does not mean that the teacher gives information to the students using traditional methods of explanation; the students are not only involved in the learning process, but also given the main role, which changes the role of the teacher from the dominant teacher to the mentor. Schools and curricula have begun to make the activity an important means of delivering the experiences in an integrated way to the students, and an integral part of the teaching methods in which these curricula are implemented. These activities provide students with useful educational experiences through practical attitudes where it is easy to recall and remember it later when students are going through similar situations in public life.

In spite of the multiplicity of teaching strategies and methods, Nawasra (2002) notes that although there is no one ideal way to teach students and provide them with knowledge, it depends on several factors: the nature of the lesson, the nature of the students and the possibilities available. The Role Playing Strategy is an effective strategy that provides the learner with a specific simulation system in which students play the different roles of individuals or groups in a real life situation and represent the way in which issues related to complex social situations are identified (Sa'ada et al., 2006). 
Students have the opportunity to explore the nature of the internal relationships of social, economic and political problems, and enable viewers to view and analyze patterns of behavior that interact with people to illustrate conflicts, values and behavioral alternatives, at the same time, General issues that enable students to analyze and critique their behavior without being embarrassed to express their opinions, thoughts and feelings freely and spontaneously (Fanish, 1991). Hamwa (2000) adds that the implementation of the role playing strategy through drama representation is one of the activities that contribute effectively to helping students learn. Playing roles through drama plays to provide comfort and harmony between the students themselves and between them and their teachers on the other hand, it is also an important means to motivate students and their excitement and courage and confidence in themselves, and they can install the experiences in their minds and call them, as well as that drama development develops the ability of students to face and solve problems.

Role play is a pattern of phenomena that students like to participate in, because it gives them the opportunity to experiment with many roles. This pattern leads to the physical, social, emotional and physical growth of students (Herr, 2002). And the role playing strategy may exceed the limits of the classroom to reach the school theater based on the texts of the play chosen by the teacher textbooks, and be related to the lives of students, and address the issues of social and political and economic and the Jordanian government sponsored this kind of theater where he saw increasing interest by the Jordanian government represented At the Ministry of Culture. The first festival of the Children's Theater began in 1994 (Zoubi and Amro, 2002).

\section{Purpose of the study}

The purpose of this study is toinvestigate the effect of using Role play strategy on the tenth grade students'performance in reading skillat public schools in Amman during the Academic year 2017/2018.

\section{Questions of the study}

The study attempts to answer the following questions:

1. Are there any statistically significant differences between tenth grade students' performances in reading skill at public schools in Amman due to the strategy of teaching? (Role Play strategy and the Current strategy?

2. Are there any statistically significant differences between tenth grade students' performances in reading skill at public schools in Amman due to gender?

3. Are there any statistically significant differences between tenth grade students'performances in reading skill at public schools in Amman due to the interaction between gender and group?

\section{Limitations of the Study}

This study is limited to all tenth grade students in the public schools in Amman/Jordan.

\section{Previous Studies}

In the study of (Sturges et al., 2009) entitled "Understanding the Protein Composite: The way of Role playing in Major Baccalaureates, which study human anatomy and physiology. This study investigated the effectiveness of role play in the major sciences classes at the undergraduate level. The target population of the study is (298) students enrolled in two divisions of human anatomy and physiology taught by the same lecturer. The study group was the section in which the role play activity was introduced, while the class taught in the traditional lecture style was the control group. The results of the study showed that participants from both groups showed a marked improvement in post-test compared with pre-test, but there were no significant differences between the two groups in the post-test.No group of the two groups showed any significant change between pre-test and post-test. However, there was a moderately positive effect on the questionnaires in terms of satisfaction and participation in the study group based on (225) questionnaires returned by both groups. The study showed that role playing is the same as the traditional lecture in terms of achievement. It was also found that role playing is beneficial in the participation of students in the learning process and in increasing their level of satisfaction.

The study of Gawakze (2005) aimed to investigate the effect of the use of drama in the development of listening comprehension skills among the fourth grade students in Jerash governorate. The study sample consisted of (38) fourth grade students in Jarash School. The sample was divided into two groups: an experimental group consisting of (19) male and female students, and a control group consisting of (14) male and female students. The results revealed that there were statistically significant differences in the performance of the fourth grade students, due to the effect of the method variable. The differences were in favor of the method of drama representation. And the absence of statistically significant differences in the performance of the fourth grade students, attributed to the effect of the gender variable, and the absence of statistically significant differences in the performance of the fourth grade students, attributed to the effect of interaction between method and gender. 
Al-Tawara (2004) conducted a study aimed at investigating the impact of a teaching program based on the use of drama, in developing the skills of oral expression among students at basic education. The study sample consisted of (97) male and female students at primary education at the SukainaBint Al Hussein School and Umm Amara school at Shoubak District. The sample was divided into two groups, the first is experimental and included (53) students from the first three grades (1, 2 and 3 grades) at SukainaBint Al Hussein School. The second was control group who studied oral expression in the prevailing way. It included (44) students from the first three grades (1, 2, 3 grade) at Um Omara School.

The results showed the superiority of the experimental group on the control group in oral expression skills with statistically significant differences, indicating the effectiveness of the dramatic play in teaching. The second and third graders of the second and third grades were above the first grade students in achievement, and there were no statistically significant differences between the second and third grade students. Results also showed no statistically significant differences in achievement between males and females,and the absence of statistically significant differences in achievement due to the interaction between the three variables (method, gender, and grade level).

Sawalha (2000) conducted a study aimed at investigating the effect of the use of drama in teaching reading texts on the development of verbal reading skills expressed in its three aspects (voice, motor, expressive, and cognitive comprehension) among fifth grade students in the public schools of BaniKenana Directorate/ Jordan. The sample consisted of (52) fifth grade students at Saham Primary School for Girls and Hartha primary school for girls in BaniKenanagovernate. The sample was divided into two groups: experimental from the fifth grade in the primary school for girls, and control who receives the same reading instruction in the usual way, included (24) students from the fifth grade in the primary school of Hartha

The results revealed that there were statistically significant differences between the average performance of female students in the experimental group and the average performance of female students in the post-test group in favor of female students in the experimental group. And there were statistical significance differences in favor of the experimental group, on the test of both sides of voice and motor expression, and the absence of statistically significant differences between the average performance of students of the experimental and control groups on both the reading comprehension and the three dimensions of the verbal expressive reading.

Hamwa (2000) conducted a study aimed at finding out the effect of using the method of drama representation on reading comprehension skills in its analytical and evaluation levels of the seventh grade students compared to the normal way in Jordan. The sample consisted of (71) students in the seventh grade, distributed in four classes in two schools (males and females). Two groups of students were chosen to be taught in drama mode while the two students were taught in the control group in the usual way. The results showed that there were statistically significant differences between the average marks of students in the post-test for reading comprehension in favor of drama representation. The absence of statistically significant differences in reading comprehension is due to gender.

\section{Design and Methodology}

\section{Variables of the Study}

The independent variables:

1. The teaching strategies (Role play strategy, and the Traditional strategy)

2. Gender; male and female

3. The dependent variable: The students' scores on the reading achievement test.

\section{Population of the Study}

The population of the study consisted of:

All the tenth grade students enrolled in the public schools in Amman in the firstsemester of the academic year 2017/2018, they were 1370 students.

\section{Participants of the Study}

The participants of the study consisted of (256) tenth grade students enrolling in the public schools in Amman in the first semester of the academic year 2017/2018

1. The students were chosen purposefully, andthey consisted of two sections, one section was assigned as experimental group (128 students, 64 males and 64 females) students, and the other as acontrol group (128students, 64 males and 64 females).

\section{Instruments of the Study}

The study utilized these instruments: 
1.Pre-test: This was used to check groups' equivalence .

2. Post-test: This was used to measure students' achievement after the treatment, it consisted of tenquestions

\section{Reliability of the Instruments}

The researcher used the test re-test technique with a pilot group, which was instructed by the teachers in these public schools themselves. At thebeginning of the treatment for two weeks, they were taught the material and they sat for a test, then, after one month they sat for the same test again. The reliability of the test was concluded usingcorrelation coefficient and found to be 0.89 . The researcher considered this value acceptable for thepurposes of the study.

\section{Validity of the Instruments}

The test was distributed to a jury of four English supervisors to judge its validity; the researchermodified the test according to their comments. The test consisted of ten questions.

\section{Procedures of the Study}

The researchers used students' marks in the pre/test to check theirequivalence. To find out the equality between the groups, means and standard deviations the pretest were calculated according to group variable, results showed a slight variancein the means of the pretest according to Group. Before the teachers began to teach the material, studentsof both groups (experimental and control) sat for a pre-test exam, and the results of this exam were areference point to compare students achievement before and after the treatment. Then, the teacher began instructing the first group using the Role play strategy and the current strategy with the second group. After the treatment the teacher conducted a test to see whether there was a difference between the groups in the students'achievement.

\section{Data Analyses}

To answer the three questions of the study, descriptive methods (means and standard deviation) wereused on pre and posttests of English reading skill with the experimental and control groups.Comparison statistical method (Two-Way ANOVA) analysis of variance was used to make acomparison between the control and the experimental groups, gender variable (male and female), andinteraction between them.

\section{Results of the Study}

\section{Findings related to the First Question}

To answer the first question of the study which states: Are there any statistically significant differences between tenth grade students' performances in reading skill at public schools in Amman due to the strategy of teaching (Role Play strategy and the Current strategy? Statistical analysis was used to calculate the means and standard deviations for post data ofEnglish reading skill achievement test within the two groups, control and experimental, shown in table 1.

Table 1: Means and Standard Deviation of Students' Scores on the Post-Test

\begin{tabular}{|l|l|l|l|l|}
\hline Group & Gender & N & Mean & SD \\
\hline \multirow{3}{*}{ Experimental } & Male & 64 & 33.34 & 4.47 \\
& Female & 64 & 33.59 & 5.99 \\
\cline { 2 - 5 } & Total & 128 & 33.47 & 5.2 \\
\hline \multirow{3}{*}{ Control } & Male & 64 & 23.66 & 4.53 \\
& Female & 64 & 29.09 & 4.08 \\
\cline { 2 - 5 } Total & Total & 128 & 26.37 & 5.0 \\
\hline & Male & 128 & 28.5 & 6.61 \\
& Female & 128 & 31.34 & 5.56 \\
\cline { 2 - 5 } & Total & 256 & 29.92 & 6.25 \\
\hline
\end{tabular}

It is obvious that the experimental group scored a higher mean score than the control group; thisindicates that Role play strategy has strong impact on the experimental group. To find out if there were statistically significant differences between the two groups' scores onthe post-test, (Two Way ANOVA) analysis was used, as presented in table 2.

Table 2: Results of Two-way (ANOVA) Analysis of the Students' Scores of the Two Groups on the Post Test

\begin{tabular}{|l|l|l|l|l|l|}
\hline Source & SumofSquares & DF & MeanSquare & F & Sig. \\
\hline Group & 258.781 & 1 & 258.781 & 11.123 & 0.001 \\
Gender & 1610.281 & 1 & 1610.281 & 69.214 & 0.000 \\
Group*Gende & 215.281 & 1 & 215.281 & 9.253 & 0.003 \\
Error & 2884.875 & 124 & 23.265 & & \\
\hline Correctedtot & $\mathbf{4 9 6 9 . 2 1 9}$ & $\mathbf{1 2 7}$ & & & \\
\hline
\end{tabular}


Table 3 shows that there were statistically significant differences in the post- test between thecontrol group and the experimental group in favor of the experimental group .This means that the using of Response-based strategy affected students' achievement.

\section{Findings Related to the Second Question}

To answer the second question of the study which states: Are there any statistically significant differences between tenth grade students' performances in reading skill at public schools in Amman due to gender? As shown in table 2, the results showed that there was a statistically significant difference in thestudents' achievement due to their gender in favor of females.

\section{Findings Related to the Third Question}

To answer the third question of the study which states:Are there any statistically significant differences between tenth grade students' performances in reading skill at public schools in Amman due to gender? As shown in table 2, the results also showed that there was no statistically significant difference $(\alpha=0,05)$ due to the interaction between gender and group. Post-Hoc Tests (Scheffe) was applied forcomparisons between sub groups, tables 3, 4 show that.

Table 3: Post-Hoc Tests (Scheffe) Result for Comparisons between Sub Groups

Multiple Comparisons Dependent Variable: Test Result Scheffe

\begin{tabular}{|l|l|l|l|l|}
\hline GROUPS & GROUPS & MeanDifferences & Std.Error & Sig. \\
\hline Malecontrol & femalecontrol & $-6.2812^{*}$ & 1.33127 & .000 \\
& maleexperimental & $-10.2812^{*}$ & 1.33127 & .000 \\
& femaleexperimental & $-12.0937^{*}$ & 1.33127 & .000 \\
\hline Femalecontrol & malecontrol & $6.2812^{*}$ & 1.33127 & .000 \\
& maleexperimental & $-4.0000^{*}$ & 1.33127 & .033 \\
& femaleexperimental & $-5.8128^{*}$ & 1.33127 & .000 \\
\hline Maleexperimental & malecontrol & $10.2812^{*}$ & 1.33127 & .000 \\
& femalecontrol & $4.0000^{*}$ & 1.33127 & .033 \\
& femaleexperimental & -1.8125 & 1.33127 & .605 \\
\hline Femaleexperimental & malecontrol & $12.0937^{*}$ & 1.33127 & .000 \\
& femalecontrol & $5.8125^{*}$ & 1.33127 & .000 \\
& maleexperimental & 1.8125 & 1.33127 & .605 \\
\hline
\end{tabular}

Based on observed means

* The mean difference is significant at the.05 level.

Table 5: Distribution of the Means for Subset Groups as a Result of Scheffe Test.

Test Result Scheffea, $b$

Means for groups in homogeneous subsets are displayed.

Based on Type 11 Sum of squares

\begin{tabular}{|l|l|c|l|l|}
\hline GROUPS & N & Subset1 & $\mathbf{2}$ & $\mathbf{3}$ \\
\hline Male & 64 & 26.0313 & 32.3125 & \\
Female & & & \\
Maleexperimental & 64 & & & 36.3125 \\
Femaleexperimental & 64 & 1.000 & 1.000 & 38.1250 \\
Sig. & & & .605 \\
\hline
\end{tabular}

The error term is Mean Square (Error) $=28.357$.

a. Uses Harmonic Mean Sample Size $=32.000$

b. Alpha $=.05$.

Tables 3, 4 showed the following:

1. There were significant differences between male and female in control group in favor offemale, whenever the means were (26.03), (32.31) respectively.

2. There were no significant differences between male and female in experimental group, whenever the means are (36.31), (38.12) respectively.

3. There were significant differences between male in control group and male inexperimental group in favor of male in experimental group, whenever the means were(26.03), (36.31) respectively.

4. There were significant differences between male in control group and female inexperimental group in favor of female in experimental, whenever the means were (26.03)(38.12) respectively. 
5. There were significant differences between female in control group and male inexperimental group in favor of male in experimental. Whenever the means were (32.31),(36.31) respectively.

6. There were significant differences between female in control group and female inexperimental group in favor of female in experimental, whenever the means were (32.31)(38.12) respectively.

\section{References}

Kumar,A,(2002):"Pattern of the self-disclosure among orphan andnon-orphan adolescents "children psychiatry."

Milne,A,etal (2012): " single paints working mother, and theeducational achievements of school children" sociology of education.

Parker, A( 2013): Residential care for children in Sinclair 1 (eds(residential care research rewiewed. London: her Majesties stationary(office.

Heath, A,Cotton, M;A:' Failure to easape: a longitudinal study offoster children educational attainment" British Journal of Social word.Jul. Oct. v, 18 (3.(

Fennema, and other (2007): " A longitudinal study of learning to use children thinking in mathematics education, journal of R.M.E

P.J..Hills (2006). Dictionary of Education, Routledge\&Keganpauls, London, Boston

Getery , P.7 Thom as , J.B. (2004). International Dictionary ofeducation, Billing \& sons LTD, London, p.81.

Nelson, Jack 8 Michaelis, John (2012). Secondary social studiesinstruction Curriculum, Evaluation, Eng. lewo cliffs, U.S.A. 